\title{
Biotransformation of the Monoterpene, Limonene, by Fusarium verticilloides
}

\author{
Brás Heleno de Oliveira* and Rogério Antônio Strapasson \\ UFPR, Departamento de Química, CP 19081. CEP 81531-970, Curitiba - PR, Brazil
}

\begin{abstract}
Limonene, the main constituent of the orange peel oil, was used as substrate for the biotransformation by the fungus Fusarium verticilloides. A hydroxylated derivative of limonene was isolated from the culture broth and characterized by spectroscopic methods. It was identified as perillyl alcohol, an important anti-cancer compound.
\end{abstract}

Key words: limonene, perillyl alcohol, biotransformation, Fusarium verticilloides

\section{INTRODUCTION}

$\mathrm{R}(+)$ limonene (1) is the main monoterpene constituent of the orange peel oil. It is estimated that the world production of limonene is around 50,000 tons/year. In Brazil its production is estimated to be about 38,500 tons/year (Thomas and Bessiére, 1989). This great availability of limonene has drawn attention of several research groups in order to transform it in derivatives with higher economic value. Several attempts have been made for the chemical transformation of that compound (Thomas and Bessiére, 1989).<smiles>CC(=O)[C@H]1CC=C(C)CC1</smiles>

1

The microbiological transformation of organic compounds is already routinely used for the industrial production of several useful compounds. This approach has also been used for the production of flavour and aroma chemicals (Hagedorn and Kaphammer, 1994).

Limonene has been subjected to biotransformations in various processes. Its biotransformation by Diplodia gossypina and
Corynespora cassiicola resulted in the hydroxylation of positions 1 and 2 (Abraham et al., 1986). With Aspergillus cellulosae the same diol mentioned above was produced as well as (+)-isopiperitone, (+)-peryllil alcohol (2) and (+)-cis-carveol (Noma, 1992). The biotransformation by a Pseudomone produced several metabolites (Dhavalikar and Bhattacharyya, 1966) and the transformation by a species of Cladosporium resulted in $\alpha$ terpineol. In another report peryllil alcohol (2) and other metabolites were described from the biotransformation of limonene by Bacillus stearothermophilus (Chang and Oriel, 1994).<smiles>C=C(C)[C@H]1CC=C(CO)CC1</smiles>

The biotransformation of limonene has also been attempted with yeasts (van Rensburg et al., 1997). Arxula adeninivorans and Yarrowia lipolytica converted limonene to perillic acid. More recently limonene was converted to alphaterpineol by Penicillium digitatum (Tan et al., 1998).

The transformation of limonene with isolated enzyme has also been carried out. A report (Braddock and Cadwallader, 1995) described

\footnotetext{
* Author for correspondence
} 
the isolation of alpha-terpineol dehydratase from Pseudomonas gladioli and its use for the transformation of limonene to alpha-terpineol.

We have been using $F$. verticilloides successfully for the biotransformation of tetracyclic diterpenoids. Our previous contribution (Oliveira and Strapasson, 1996) in this area showed that this fungus biotransformed isosteviol (3) in the $7 \alpha-\mathrm{OH}$ (4) and $12 \beta-\mathrm{OH}$ (5) derivatives.

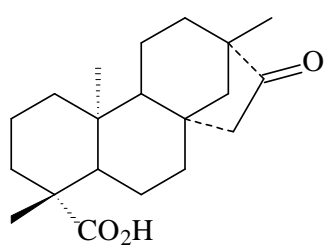

3

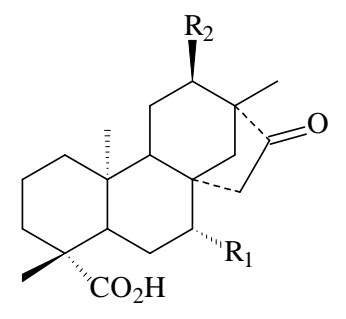

$4 \mathrm{R} 1=\mathrm{OH} ; \mathrm{R}_{2}=\mathrm{H}$

$5 \mathrm{R} 1=\mathrm{H} ; \mathrm{R} 2=\mathrm{OH}$
$F$. verticilloides has not been previously used for the transformation of limonene. Therefore we decided to see whether this fungus would be able to transform limonene and to isolate and chemically characterize the metabolites produced.

\section{MATERIALS AND METHODS}

\section{Culture Media}

a) Potato-Dextrose-Agar, for the preservation of the fungus, contained $(\mathrm{g} / \mathrm{L})$ : peeled simmered potatoes (200.0), agar (20.0), glucose (15.0).

b) Liquid Medium, for the biotransformation experiments, contained $(\mathrm{g} / \mathrm{L})$ : corn steep liquor (8.0), yeast extract (2.0), glucose (10.0). pH was adjusted to 7.0 before it was autoclaved.

The culture media were autoclaved at $121^{\circ}$ for 20 minutes.

\section{Chromatography}

a) Thin layer chromatography: TLC was carried out using silica plates (Merck Art. \# 5554) and elution was made with ethyl acetate/hexane (1:9 V/V). Colour reagent was: anisaldehyde (0.6 $\mathrm{mL})$, conc. sulphuric acid $(1.0 \mathrm{~mL})$, glacial acetic acid $(50.0 \mathrm{~mL})$. Plates were sprayed with the reagent and then heated at $100{ }^{\circ} \mathrm{C}$ until color developed.

b) Column chromatography: $\mathrm{CC}$ was carried out with silica gel 60 (Merck Art. \# 9385) and elution was made under low pressure (Still et al., 1978).

\section{Purification of Limonene}

$\mathrm{R}-(+)$-limonene was fractionated in a silica gel column and elution was made with hexane. Its identity was confirmed by proton nuclear magnetic resonance spectroscopy $\left({ }^{1} \mathrm{H}\right.$ NMR $)$.

\section{Biotransformations}

a) Small Scale Experiment: Four $250 \mathrm{~mL}$ conical flasks containing $50 \mathrm{~mL}$ of liquid medium were inoculated with the mycelium of a seed culture of $F$. verticilloides I33 (Sacc.) Nirenberg. The flasks were incubated at $30{ }^{\circ} \mathrm{C}$ on a rotary shaker at $100 \mathrm{rpm}$. After $24 \mathrm{~h} 0.1 \mathrm{~mL}$ of limonene was added to three flasks and the fourth one was kept as control. A new addition of limonene was made after another $24 \mathrm{~h}$. Twelve $h$ later the contents of the flasks were filtered and the mycelia were washed with dichloromethane $(50 \mathrm{~mL})$. The filtrate was extracted with the same solvent $(3 \times 50 \mathrm{~mL})$, the extracts were combined and analyzed by TLC.

b) Preparative Experiment: Four $1000 \mathrm{~mL}$ conical flasks containing $200 \mathrm{~mL}$ of liquid medium were inoculated with a seed culture of $F$. verticilloides and the flasks were incubated at $30{ }^{\circ} \mathrm{C}$ on a rotary shaker at $100 \mathrm{rpm}$. After $24 \mathrm{~h}$, $0.25 \mathrm{~mL}$ of limonene was added to three flasks and the fourth one was kept as control. A new addition of limonene was made after another 24 $h$. Twelve $h$ later, the contents of the flasks were filtered and the mycelia were washed with dichloromethane $(100 \mathrm{~mL})$. The filtrate was extracted with the same solvent $(3 \mathrm{X} 200 \mathrm{~mL})$, the extracts were combined, dried with anhydrous sodium sulfate, filtered and the solvent was evaporated in a rotary evaporator at reduced pressure. The crude extract thus obtained was fractionated in a silica gel column $(3 \mathrm{X} 15 \mathrm{~cm})$ using dichloromethane as eluent.

RESULTS AND DISCUSSION 
The purification of limonene by CC resulted in a pure compound whose proton nuclear magnetic resonance data confirmed the identity of the compound: ${ }^{1} \mathrm{H}$ NMR (200 MHz, $\mathrm{CDCl}_{3}, \delta$ ): 1,5 $(2 \mathrm{H}, \mathrm{m}, \mathrm{H}-5), 1,65$ (3H, s, H-7), 1,75 (3H, s, H10), 1,9 (2H, m, H-3), 1,9 (2H, m, H-6), 2,1 (H, m, H-4), 4,7 (2H, s, H-9), 5,4 (H, sl, H-2). The extract obtained from the broth of the small scale screening experiment showed that new metabolites were produced in the experimental flasks. In the preparative scale experiment the fractionation of the crude extract led to the isolation of a new metabolite $(30 \mathrm{mg})$. It was an oily compound and had the following spectroscopic data: IR: 3325, 3076, 2978-2819, 1644, 1438, $1374 \mathrm{~cm}^{-1}$; ${ }^{1} \mathrm{H}$ NMR (200 MHz, $\left.\mathrm{CDCl}_{3}, \delta\right): 1,75(3 \mathrm{H}, \mathrm{s}, \mathrm{H}-10), 4,00(2 \mathrm{H}, \mathrm{s}, \mathrm{H}-$ 7), $4,75(2 \mathrm{H}, \mathrm{s}, \mathrm{H}-9), 5,70(1 \mathrm{H}, \mathrm{s}, \mathrm{H}-2)$. The infrared spectrum of the new metabolite had a large band at $3325 \mathrm{~cm}^{-1}$, indicative of an alcohol. The ${ }^{1} \mathrm{H}$ NMR spectrum showed a singlet at $1.75 \mathrm{ppm}$ corresponding to the $\mathrm{C}-10$ methyl group and a resonance at $4.00 \mathrm{ppm}$, attributed to a $-\mathrm{CH}_{2} \mathrm{OH}$. This resonance indicated that a hydroxylation had indeed happened. The resonances of the vinylic protons H-9 and H-2 occurred at 4.75 and 5.70, respectively. The ${ }^{13} \mathrm{C}$ NMR spectrum confirmed the ${ }^{1} \mathrm{H}$ NMR findings. The olefinic carbons $\mathrm{C}-1$ and $\mathrm{C}-2$ produced resonances at $137.20 \mathrm{e}$ 122.26, respectively. The C-10 methyl resonance was observed at 20.56. Comparing with the spectrum of limonene (table 1) we observed that C-7 shifted downfield (from 23.34 to 66.91) as well as $\mathrm{C}-1$ (from 133.79 to 137.20). C-6, on the other hand, shifted upfield (from 30.70 to 25.89). Therefore the hydroxylation occurred at C-7 and the metabolite was characterized as peryllil alcohol (2).
Table 1: ${ }^{13} \mathrm{C}$ NMR of (+)-Limonene and Peryllil Alcohol

\begin{tabular}{rrr}
\hline $\mathrm{C}$ & Limonene & Peryllil Alcohol \\
\hline 1 & 133.79 & 137.20 \\
\hline 2 & 120.71 & 122.26 \\
\hline 3 & 30.48 & 30.20 \\
\hline 4 & 41.00 & 40.97 \\
\hline 5 & 27.81 & 27.27 \\
\hline 6 & 30.70 & 25.89 \\
\hline 7 & 23.34 & 66.91 \\
\hline 8 & 150.33 & 149.83 \\
\hline 9 & 108.40 & 108.58 \\
\hline 10 & 20.67 & 20.56 \\
\hline
\end{tabular}

To the best of our knowledge this is the first description of preparation of peryllil (2) alcohol from limonene, by biotransformation using $F$. verticilloides.

The importance of peryllil alcohol is derived from the possibility of easily converting it to perilaldehyde, the oxyme of which (6) is a known sweetener 2000 times as sweet as sucrose. This sweetener is commercial in Japan and it is known as perilartine.<smiles>C=C(C)[C]1CC=C(C=NO)CC1</smiles>

Another very important property of peryllil alcohol (2) is its anti-cancer activity. It is a potent inhibitor of proliferation of some cancer cell lines (Bardon et al., 1998). Because of this property the compound have entered clinical trials for possible use against certain types of cancer.

\section{ACKNOWLEDGMENTS}

We are grateful to $\mathrm{CNPq}$ (Brazil) for the financial support. We are also grateful to Fundação Oswaldo Cruz for providing the fungus, Fusarium verticilloides. 


\section{RESUMO}

Limoneno, o principal componente do óleo da casca da laranja, foi usado como substrato para a biotransformação pelo fungo Fusarium verticilloides. Um derivado hidroxilado do limoneno foi isolado do caldo de cultura e caracterizado através de métodos espectroscópicos. Ele foi identificado como álcool perílico.

\section{REFERENCES}

Abraham, W.R., Stumpf, B. and Kieslich, K. (1986) Microbial Transformations of Terpenoids With 1p-Menthene Skeleton. App. Microbiol. Biotechnol., 24, 24-30.

Bardon S., Picard, K., Martel, P. (1998) Monoterpenes Inhibit Cell Growth, Cell Cycle Progression, and Cyclin D1 Gene Gxpression in Human Breast Cancer Cell Lines. Nutr. Cancer, 32, 1-7.

Braddock, R.J., $\quad$ Cadwallader, K.R., (1995) Bioconversion of Citrus d-Limonene A.C.S. Symp. Ser., 596, 142-148.

Chang, H.C. and Oriel, P. (1994) Bioproduction of Perillyl Alcohol and Related Monoterpenes by Isolates of Bacillus stearothermophillus. J. Food Sci. , 59, 660662.

Dhavalikar, R.S. and Bhattacharyya, P.K. (1966) Microbiological Transformation of Terpenes: Part VIII - Fermentation of
Limonene by a Soil Pseudomonad. Indian J. Biochem., 3, 144-157.

Hagedorn, S. and Kaphammer, B. (1994) Microbial Biocatalysis in the Generation of Flavor and Fragrance Chemicals. Annu. Rev. Microbiol., 48, 773-800.

Noma, Y., Yamasaki, S., Asakawa, Y. (1992) Biotransformation of Limonene and Related Compounds by Aspergillus cellulosae. Phytochemistry, 31, 2725

Oliveira, B.H. and Strapasson, R.A. (1996) The Biotransformation of Isosteviol by Fusarium verticilloides. Phytochemistry 43, 393-395.

van Rensburg, E., Moleleki, N., van der Walt, J.P., Botes, P.J., van Dyk, M.S. (1997) Biotransformation of (+)limonene and (-) piperitone by yeasts and yeast-like fungi. Biotechnol. Lett. 19, 779-782.)

Still, W.C., Kahn, M. and Mitra, A. (1978) Rapid Chromatographic Technique for Preparative Separations With Moderate Resolution. J.Org.Chem, 43, 2923-2925.

Tan, Q., Day, D.F., Cadwallader, K.R. (1998) Bioconversion of (R)-(+)-limonene by Penicillium digitatum (NRRL 1202) Process Biochem., 33, 29-37.

Thomas, A.F., Bessiére, Y., (1989) Limonene Nat. Prod. Rep., 291-309.

Received: September 03, 1998; Revised: March 03, 1999; Accepted: July 05, 1999. 